\title{
BERGESERNYA MAKNA DAN FUNGSI SURAU DALAM KEHIDUPAN MASYARAKAT MINANGKABAU MELALUI FILM DOKUMENTER “SURAU KITO" DENGAN GAYA EKSPOSITORI
}

\author{
Rizqy Vajra J \\ Endang Mulyaningsih \\ Lilik Kustanto \\ Jurusan Film \& Televisi, Fakultas Seni Media Rekam, Institut Seni Indonesia Yogyakarta \\ Jl. Parangtritis km. 6.5 Yogyakarta Telp. (0274) 381047
}

\begin{abstract}
ABSTRAK
Sovie montage menjadi teknik yang mengupayakan secara maksimal kekuatan visual yang dipotensikan dalam suatu film. Makna akan tercipta dari deretan gambar yang disajikan di suatu sequence. Pengalaman artistik kreator dapat tereksplorasi apabila teknik ini yang ingin dicapai. Film berbicara tentang konflik. Maka, konflik juga dapat diceritakan melalui soviet montage, untuk menggambarkan makna yang lebih dalam secara visual.

Bercerita tentang bagaimana peranan surau dalam memebentuk karakter masyarakat Minangkabau yang makin memudar. Film dokumenter ini membantu kita untuk mengehtahui apa makana, fungsi, dan faktor-faktor kemerosotan surau dalam kehidupan masyarakat Minangkabau.

Bagaimana sejarah berdirinya surau serta mankna dan fungsi surau dalam membentuk karakter masyarakat Minangkabau, dan faktor faktor yang menyebabkan bergesernya makna dan fungsi surau dalam membentuk karakter masyarakat Minangkabau. Bagaimana dampak bagi masyarakat Minangkabau jika surau hilang dan tidak difungsikan sebagai mestinya.

Film dokumenter "Surau Kito" merupakan hasil karya seni tugas akhir yang menerapkan gaya dokumenter ekspositori. Penerapan gaya dokumenter ekspositori digunakan untuk menhgarahkan penonton ke sebuah sudut pandang dimana surau sangat berperan penting dalam pembentukan karakter masyarakat Minangkabau yang perlu dijaga dan difungsikan kembali.
\end{abstract}

Kata Kunci : Film, Dokumenter, Ekspoditori, Surau, Minangkabau

\section{Latar Belakang Penciptaan}

Eforia orde reformasi telah lama menumbuhkan keberanian daerah untuk berbicara guna menentukan nasibnya sendiri. Tuntutan daerah untuk menentukan nasibnya sendiri kemudian diwujudkan melalui kebijakan otonomi daerah. Rupanya ruang publik yang cukup lebar itu masih banyak disalahtafsirkan. Tafsiran-tafsiran pribadi atas berbagai isu lokal, misalnya otonomi daerah dan kembali ke Nagari, menciptakan wacana yang tidak berujung dan inovatif. Pada akhirnya reformasi menjadi gerakan yang tidak tuntas di masyarakat Minangkabau.

Salah satu di antara wacana publik yang muncul sejak lama adalah gerakan kembali ke surau. Wacana gerakan kembali ke surau dari era otonomi daerah ini merupakan sesuatu yang sudah lama. Karena itu, masih banyak orang yang memberikan tafsira nya sendiri-sendiri. Interprestasi terhadap ungkapan itu masih diperdebatkan, apalagi jika dilanjutkan pada tahap pelaksanaan. 


\section{Rizqy Vajra J, Endang Mulyaningsih, Lilik Kustanto}

Bergesernya Makna dan Fungsi Surau Dalam Kehidupan Masyarakat Minangkabau Melalui Film Dokumenter

Generasi muda yang lahir di tahun 1990-an banyak juga yang tidak memahami semangat surau, mereka yang lahir pada periode itu sudah tidak dibesarkan dalam kultur surau. Keterlibatan mereka dengan kata surau sebatas apa yang mereka baca dan dengar. Surau yang dahulu demikian kukuh sebagai benteng moral masyarakat Minangkabau kini memudar. Surau mulai ditinggalkan oleh generasi muda Minangkabau, dahulu surau mampu menghasilkan tokoh tokoh besar di kancah nasional maupun internasional. Seperti Mohammad Hatta, Sutan Malaka, Haji Abdul Malik Karim Amirullah, Mohammad Yamin dan masih banyak lagi tokoh-tokoh yang lahir dan dibesarkan dari pendidikan surau yang saat ini ditinggalkan oleh generasi muda Minangkabau, bahkan bisa dikatakan peranan surau dalam kehidupan sosial dan budaya masyarakat Minangkabau hampir hilang. Padahal surau memiliki posisi yang strategis dalam pembentukan karakter masyarakat Minangkabau.

Surau merupakan lembaga pendidikan tertua di Minangkabau, bahkan ada beberapa pendapat yang menyebutkan bahwa sebelum Islam masuk ke Minangkabau surau sudah ada, diama pada saat itu surau berfungsi sebagai tempat pendidikan dan tempat tidur bagi lelaki Minangkabau yang sudah dewasa. Dengan datangnya Islam, surau juga mengalami proses Islamisasi, tanpa harus mengalami perubahan nama. Selanjutnya surau semakin berkembang di Minangkabau. Di samping fungsinya sebagai tempat pendidikan agama, surau juga merupakan tempat para ninik mamak atau tokoh adat bermusyawarah, tempat melatih berkesenian seperti seni tari, bela diri, randai dan lainnya, surau juga sebagai tempat untuk memberikan pencerahaan dan wawasan kepada sanak famili, tempat mengajarkan Al-Qur'an dan Hadis serta ilmu lainnya, juga tempat mengajarkan adat, sopan santun, ilmu beladiri (silat Minang) dan juga sebagai tempat tidur bagi pemuda yang mulai remaja dan bagi laki-laki tua yang sudah bercerai, ini barangkali sudah merupakan aturan yang berlaku di Minangkabau, karena lelaki Minangkabau tidak disiapkan kamar dirumahnya, maka mereka bermalam di surau. Surau di Minangkabau biasanya merupakan milik suku atau kaum masyarakat Minangkabau, setiap suku atau kaum di Minangkabau mempunyai suraunya masing masing.

Sekarang di era globalisasi yang serba terbuka dan teknologi informasi yang canggih, keberadaan surau sudah tergeser dari fungsi semula, surau dipandang tidak lagi menjadi bagian prinsip adat Minangkabau yang tetap ada kemurniannya dalam kehidupan adat istiadat masyarakat Minangkabau, semuanya sudah tergerus, serta sudah bergeser jauh dari nilai-nilai awal. Surau sudah banyak ditinggalkan 
kaum, masyarakat jorong, malah anak kemenakan banyak yang tidak paham dengan peran dan fungsi surau di Minangkabau. Sehingga sudah ada pembenaran bersama di antara anak nagari dan masyarakat Minangkabau bahwa surau tidak lagi relevan untuk zaman sekarang.

Ketidak tahuan masyarakat akan fungsi dan makna dari surau membuat masyarakat Minangkabau semakin meninggalkan surau. Ditambah beberapa sumber yang hanya menampilkan beberapa sisi dari makna dan fungsi surau yang hanya sedikit membuat masyarakat menjadi kekurangan sumber untuk mengetahui bagaimana sesungguhnya makna dan fugsi dari surau dalam kehidupan masyarakat Minangkabau. Untuk mengetahui bagaimana makna dan fungsi dari surau tentu harus melihat dari banyak sisi yang lainnya sehingga masyarakat Minangkabau tidak semakin terjebak dalam ketidaktahuan.

Oleh karena itu pemilahan film dokumenter untuk menjadi salah satu sumber pengetahuan masyarakat akan makna dan fungsi dari surau dianggap sangat tepat, melalui film dokumenter, masyarakat akan diberi suguhan fakta- fakta akan makna dan fungsi sebenarnya dari surau, mulai dari asal usul, bagaimana surau berperan dalam membentuk karakter masyakarat Minangkabau, hingga bagaimana surau menjadi lembaga pendidikan agama, adat dan sosial didalam masyarakat Minangkabau. Fakta tersebut didukung oleh narasumber yang kredibel dan memiliki kedekatan dengan surau, mulai dari bagaimana mereka hidup di dalam lingkungan surau, hingga mereka melihat bagaimana perkembangan surau yang mulai kehilangan makna dan fungsinya.

Dokumenter ekspositori dipilih menjadi metode untuk menyampaikan halhal tersebut. Di samping dokumenter dengan metode ekspositori dapat menyampaikan opini langsung dari seorang narasumber yang memiliki wawasan mengenai makna dan fungsi surau, format dokumenter ekspositori dipilih karena mempunyai kekuatan untuk menghantarkan langsung informasi yang disampaikan oleh narasumber baik melalui teks maupun suara dengan sudut pandang tertentu. Kedua media tersebut berbicara sebagai orang ketiga kepada penonton, ada kesadaran bahwa mereka sedang berhadapan dengan penonton. Penjelasan dari wawancara maupun narasi cenderung terpisah dari alur film, mereka memberikan komentar terhadap apa yang terjadi, ataupun pengetahuan yang dimiliki tentang kejadian yang bersangkutan. Itu sebabnya, pesan atau point of view (POV) dari ekspositori sering dielaborasi lewat suara atau teks daripada lewat gambar. Dan jika pada film fiksi gambar disusun berdasarkan kontinuitas waktu dan tempat, yang berasaskan aturan tata gambar, maka pada ekspositori gambar disusun sebagai 


\section{Rizqy Vajra J, Endang Mulyaningsih, Lilik Kustanto}

Bergesernya Makna dan Fungsi Surau Dalam Kehidupan Masyarakat Minangkabau Melalui Film Dokumenter

penunjang argumentasi yang disampaikan lewat narasi, berdasarkan naskah yang sudah dibuat dengan prioritas tertentu, sehingga pada film dengan gaya ini memungkinkan sutradara untuk bisa membuat naskah film pada awal produksi atau sebelum shooting dilakukan. Pemilahan penciptaan film dokumenter ini diharapkan dapat menambah pengetahuan masyarakat Minangkabau akan makna dan fungsi dari surau secara langsung dari narasumber.

\section{Ide Penciptaan Karya}

Hidup dan dibesarkan dengan kebudayaan Minangkabau tidak menjamin seseorang mengetahui semua sejarah budaya Minangkabau, ketidaktahuan tersebut menimbulkan berbagai pertanyaan, namun semua pertanyaan itu belum terjawab. Sejarah tentang budaya Minangkabau tidak banyak diketahui karena kebudayaan dari masyarakat itu sendiri, sejarah Minangkabau sangat jarang dicatat melalui lontar ataupun artefak-artefak seperti kebudayaan lainnya, masyarakat Minangkabau lebih senang menurunkan sejarah kebudayaannya melalui karya-karya lisan, seperti kaba, dan gurindam yang mana karya-karya tersebut lebih banyak menggunakan majas metafora, sehingga karya tersebut sangat sulit dipahami artinya oleh generasi muda. Semua itu menjadikan sumber bacaan dan rujukan tentang sejarah kebudayaan Minangkabau sangat sedikit.
Salah satu kebudayaan Minangkabau yang menjadi pertanyaan adalah bagaimana makna dan fungsi sesungguhnya dari surau dalam kehidupan Masyarakat Minangkabau, karena jikalau dikatakan surau mempunyai fungsi dengan latar belakang agama lalu Masjid berfungsi sebagai apa, begitupun jika dilihat dari sudut pandang adat yang mempunyai rumah Gadang dan balai adat.

Keinginan untuk mencari dan menyampaikan informasi mengenai makna dan fungsi surau dalam kehidupan masyarakat Minangkabau membuat dipilihnya format dokumenter sebagai format penggarapan film "Surau Kito". Dokumenter "Surau Kito" akan bercerita tentang bagaimana makna dan fungsi surau dalam kehidupan masyarkat Minangkabau yang sebenarnya. Sehingga pendekatan ekspositori digunakan sebagai cara bertutur yang mengarahkan penonton pada suatu sudut pandang secara langsung, untuk menjelaskan tentang berbagai makna dan fungsi surau yang ada dalam kehidupan masyarakat Minangkabau.

Cerita akan diawali dengan penampilan scene berupa gambaran secara garis besar mengenai makna dan fungsi surau yang ada di Minangkabau pada masa lalu. Hal tersebut guna memancing ketertarikan audience terhadap film ini karena keingintahuan masyarakat khususnya di Minangkabau tentang budaya dan kedigdayaan masa lalu sangatlah tinggi. 
Semakin lama, penonton akan diarahkan pada sudut pandang baru mengenai perubahan dan pergeseran makna dan fungsi surau dari berbagai faktor, pola kehidupan masyarakat Minangkabau pada saat sekarang, dan kemudian ditutup pada sebuah kesimpulan bagaimana cara agar makna dan fungsi surau tersebut bisa kembali pada makna dan fungsi semulanya guna akan tujuan utama dari institusi surau dalam pembentukan suatu karakter masyarakat terutama masyarakat Minangkabau atau yang sering disebut dengan istilah "kembali ke Surau".

Seluruh rangkain cerita akan dirangkai melalui narasi yang disampaikan menggunakan teknik penyampaian karya sastra lisan kaba dan gurindam, narasi akan banyak memakai bahasa daerah Minangkabau dan menggunakan majas metafora yang diperhalus guna mudah memahami agar sesuai dengan kebudayan lisan masyarakat Minangkabau, narasi yang menggunakan bahasa Minangkabau akan diberi text pengalihan bahasa dalam proses editing. Pemilihan cara bertutur narasi tersebut dipilih karena akan menguatkan keterkaitan emosi penenonton terhadap film ini, dan juga sebagai bentuk pelestarian kebudayaan lisan Minangkabau.

Film "Surau Kito" merupakan film dokumenter yang berlatar belakang kebudayaan Minangkabau, sehingga nuansa etnis Minangkabau menjadi kunci pokok dalam konsep secara keseluruhan. Nuansa tersebut juga akan dibangun melalui ilustrasi musik menggunakan alat musik tradisional Minangkabau seperti saluang, pupuik, rabab, talepong, dan sarunai, yang dipadukan menjadi sebuah instrumen yang mengiringi mood, argumen narasumber, dan narasai dalam film. Di Minangkabau, setiap instrumen musik memiliki karakteristik dan filosofi yang berbeda dan dipergunakan pada momen yang berbeda pula, maka setiap babak penuturan akan menggunakan musik yang dapat mendukung suasana.

Dari segi bahasa yang akan dipergunakan, narasumber dibebaskan untuk memilih bahasa dalam menyampaikan argumen. Jika narasumber menggunakan bahasa Minangkabau, maka dalam proses editing gambar diberi text pengalihan bahasa. Hal tersebut bukan semata-mata untuk memberi sentuhan budaya Minangkabau dalam wawancara, namun juga memberi kenyamanan dalam penyampaian argumen, kedekatan terhadap narasumber sangat dibutuhkan dalam pembuatan film.

Untuk visual yang akan ditampilkan dalam film ini akan mengambil beberapa footage dari arsip nasional maupun perpustakaan daerah tentang bagaimana kehidupan masyarakat Minangkabau pada saat surau belum kehilangan makna dan fungsinya, sedengkan untuk visual selain wawancara, film ini juga akan menampilkan seperti kegiatan remaja di sekitar surau, 


\section{Rizqy Vajra J, Endang Mulyaningsih, Lilik Kustanto}

Bergesernya Makna dan Fungsi Surau Dalam Kehidupan Masyarakat Minangkabau Melalui Film Dokumenter

latihan silat, proses anak anak belajar mengaji di surau, rapat pemuka adat yang dilakukan di surau. Selain itu gambaran bagaimana kehidupan masyrakat Minangkabau pada saat sekarang juga akan ditampilkan, seperti, anak laki laki tidak malu lagi untuk tidur dirumah dan bercanda gurau dengan adik perempuan, beberapa surau yang mulai roboh dimakan usia, dan pergaulan generasi muda Minangkabau yang jauh dari nilai-nilai luhur Surau dan masyarakat Minangkabau. Semua visual akan mendukung informasi yang diberikan oleh narasumber.

Dalam proses editing Dokumenter "Surau Kito" dimana cerita akan dibentuk melalui statement narasumber. Dalam mendukung sebuah realitas tentu membutuhkan bukti-bukti terkait statement tersebut yang akan disisipkan di antara statement narasumber, sehingga akan menggunakan konsep editing kompilasi untuk memberikan struktur naratif yang menarik. Editing kompilasi merupakan salah satu bentuk editing yang menerapkan metode penyusunan gambar berdasarkan narasi atau penyampaian informasi melalui audio, sehingga gambar akan mengikuti penjelasan yang sudah ada.

\section{Tujuan dan Manfaat Karya}

\section{Tujuan}

a. Memberi pengetahuan akan makna dan fungsi Surau.

b. Mengetahui persepsi masyarakat mengenai makna dan fungsi Surau.

c. Mengetahui pendapat para ahli mengenai makna dan fungsi Surau.

d. Mendeskripsikan peran Surau dalam sejarah Minangkabau.

e. Mengetahui proses perkembangan kehidupan Surau.

\section{Manfaat}

a. Mengetengahkan makna dan fungsi Surau yang selama ini sudah mulai ditinggalakan.

b. Melestarikan budaya dan adat istiadat Minangkabau mengenai makna dan fungsi Surau.

c. Menambah wawasan tentang akar budaya dan adat istiadat Minangakabau yang mulai terkikis terkhusus mengenai makna dan fungsi Surau.

d. Eksplorasi warisan kebijakan nenek moyang masyarakat Minangkabau untuk bisa dimanfaatkan dalam kehidupan sehari-hari.

e. Menghidupkan kembali makna dan fungsi Surau dalam kehidupan masyarakat Minangkabau

\section{Objek Penciptaan}

Surau adalah institusi yang berfungsi untuk mengembangkan nilai-nilai moral agama dan budaya di Minangkabau. Dari suraulah cikal bakal keutuhan dan keutamaan masyarakat Minangkabau beradat dan beragama dijalankan secara bersamaan. Keberhasilan ditandai apabila anak pandai 
mengaji, taat beribadah, berakhlak dan berbudi pekerti luhur, mampu memakaikan tata krama adat, pandai petatah petitih adat, menguasai kesenian anak nagari. surau telah menjalankan proses pendidikan yang berkarakter. Karenanya falsafah "adat basandi syark, syarak basandi kitabullah," ( adat berlandaskan syariat, syariat berlandasakan kitab Allah) dapat dilihat dalam kehidupan surau.

Surau adalah milik kaum atau suku, surau dalam sistem adat Minangkabau didirikan oleh suatu kaum tertentu sebagai bangunan pelengkap rumah gadang (rumah adat/besar), tempat di mana keluarga yang saparuik (berasal dari satu perut atau keturunan) berdiam. Biasanya dibangun di atas tanah matrilineal, tanah ulayat (tanah yang digunakan secara komunal) yang disediakan nagari (desa adat di Minangkabau), atau tanah wakaf yang diberikan penduduk nagari. Namun demikian tidak setiap rumah gadang memiliki surau, karena surau yang telah ada masih dapat menampung pemuda, para musafir dan pedagang yang melewati surau desa pada saat larut malam dalam perjalanannya. Dengan demikian para pemuda yang tinggal dan bermalam di surau dapat mengetahui informasi yang terjadi di luar desa mereka, serta situasi kehidupan di rantau.

Bagi masyarakat Minangkabau surau tidak saja menjadi simbol agama, tetapi surau juga menjadi simbol adat Minangkabau.
Maksudnya, selain untuk tempat ibadah dan pendalaman nilai-nilai agama, Surau juga menjadi semacam pusat pendidikan budaya dan adat istiadat Minangkabau.

Surau merupakan lembaga pendidikan tertua di Minangkabau, bahkan ada beberapa pendapat yang menyebutkan bahwa sebelum Islam masuk ke Minangkabau surau sudah ada. Dengan datangnya Islam, surau juga mengalami proses Islamisasi, tanpa harus mengalami perubahan nama. Selanjutnya surau semakin berkembang di Minangkabau. Di samping fungsinya sebagai tempat pendidikan agama, juga merupakan tempat para ninik mamak atau tokoh adat bermusyawarah, tempat berlatih kesenian seperti seni tari, randai dan lainya.

Di suraulah dulunya anak laki-laki yang mulai menginjak masa remajanya lebih banyak menghabiskan waktunya setiap hari. Di surau mereka belajar mengaji al Quran dan juga tafsirnya, ilmu hadis, Aqidah, Ibadah, Muamalah, dan materi keislaman lainnya. Di surau juga mereka belajar tentang petatah-petitih adat Minangkabau, beladiri, randai, dan berbagai kesenian serta adat budaya Minangkabau lainnya. Di surau jugalah mereka ditempa dan dipersiapkan untuk menjadi pribadi yang siap menanggung beban dan amanah di kemudian harinya.

Terkait dengan fungsi surau pada masa lalu di Minangkabau yang ternyata tidak hanya sebatas tempat ibadah saja, 


\section{Rizqy Vajra J, Endang Mulyaningsih, Lilik Kustanto}

Bergesernya Makna dan Fungsi Surau Dalam Kehidupan Masyarakat Minangkabau Melalui Film Dokumenter

tetapi juga memainkan peranan yang cukup banyak dalam kehidupan sosial kemasyarakatan, maka tak salah kiranya apabila dikatakan surau sebagai salah satu pranata sosial di masyarakat Minangkabau. Pranata yang dikenal sebagai salah satu padanan kata untuk institusi, didefenisikan oleh Koendjaraningrat sebagai sistem norma khusus yang menata suatu rangkaian tindakan berpola mantap guna memenuhi suatu keperluan khusus dari manusia dalam masyarakat.

Surau menyangkut fungsinya sebagai salah satu atau bagian dari pranata penting dalam masyarakat Minangkabau, telah memainkan peranannya untuk memenuhi berbagai keperluan masyarakat dalam kehidupan sosial bermasyarakat. Sebut saja fungsi surau sebagai institusi pendidikan dan pengajaran bagi anak- anak remaja di Minangkabau, selain itu surau juga memainkan fungsinya dalam sosialisasi berbagai informasi yang harus di ketahui masyarakat.

\section{Konsep Karya}

Ekspositori identik dengan membentuk statement yang digunakan untuk menyampaikan tema film. Konsep film "Surau Kito" adalah membentuk cerita dari kumpulan wawancara atau statement dengan perspektif yang berbeda-beda, begitu juga konsep dramatiknya. Sehingga film ini membutuhkan konten yang jelas, gambar yang menarik, dan narasumber yang mempunyai kedekatan dengan surau guna menyampaikan premis yang ingin dicapai.

Alur film menjadi menarik ketika statement yang didapat memiliki pendapat yang berbeda-beda dari berbagai tokoh yang hidup di lingkungan surau. Gaya ekspositori sengaja digunakan karena film ini ingin menjelaskan objek surau di tengah masyarakat Minangkabau itu sendiri dari berbagai sudut pandang narasumber menurut kompetensi mereka masing-masing. Sudut pandang yang berbeda-beda tersebut dapat membuat sebuah koneksi dari masing masing statement dan membentuk bagan alur sendiri ketika diproses editing digabungkan sesuai treatment yang sudah dirancang sebelumnya.

Struktur yang digunakan dalam film dokumenter ini adalah tiga babak. Struktur tersebut dapat dilihat dalam konstruksinya yang menggunakan struktur tiga babak, dimana segmen pertama berisi tentang pengenalan konflik, segmen kedua berisi tentang konflik, dan segmen ketiga berisi tentang resolusi konflik yang disusun lewat treatment sebagai acuan utama dalam pembuatannya.

Pada bagian awal, untuk merangsang rasa ingin tahu penonton, diketengahkan bagaimana sejarah berdirinya surau serta mankna dan fungsi surau dalam membentuk karakter masyarakat Minangkabau, dan pada bagian tengah dikisahkan faktor faktor yang menyebabkan bergesernya makna dan fungsi 
surau dalam membentuk karakter masyarakat Minangkabau. Dibagian akhir, dipaparkan perihal bagaimana dampak bagi masyarakat Minangkabau jika surau hilang dan tidak difungsikan sebagai mestinya, dan ini yang menjadi klimaks yang dramatis. Konsep pendekatan naratif di film dokumenter ini adalah visual dengan narasi atau isi penjelasan dari narasumber yang selalu diseimbangkan dan dirangkai menjadi sebuah jalan cerita.

Kehadiran film ini bertujuan untuk memancing penontonnya untuk ikut berfikir tentang fenomena bergesernya eksistensi, makna dan fungsi surau dalam kehidupan masyarakat Minangkabau pada saat sekarang ini. Objek surau sendiri sudah sempat menjadi perdebatan sejak beberapa waktu yang lalu dan tidak menemukan konklusi hingga saat ini, hingga akhirnya isu ini mulai mengabur. Film ini ingin mengungkit isu ini dengan berbagai sudut pandang yang berbeda sehingga dapat menjadi bahan evaluasi bersama sekaligus sebagai pengingat bahwa isu tentang surau akan terus ada ketika surau itu sendiri masih dianggap penting oleh sebagian masyarakat Minangkabau namun makna dan fungsi dari surau itu masih samar - samar.

\section{Desain Produksi}

Kategori Program : Non Cerita

Format Program : Dokumenter
Nama Program : "Surau Kito"

Durasi : 30 menit

Tema

: Makna dan fungsi

Surau di Minangkabau

Segmentasi

Usia

: Remaja dan Dewasa

(12 tahun- 40 tahun)

Jenis kelamin $\quad$ : Perempuan \& lakilaki

Penayangan : Festival dan

Komunitas

Sinopsis

Surau bagai masyarakat Minangkabau pada masa lalu sangatlah penting dalam membentuk karakter dan kepribadian mereka, di surau masyarakat Minangkabau dibentuk agar berguna bagi lingkungan sekitar dan taat dalam beragama serta mempunyai kepribadian yang menjunjung tinggi nilai adat budaya Minangkabau.

Namun banyak faktor faktor yang menyebabkan surau ditinggalkan dan tidak lagi dianggap sebagai sebuah institusi yang penting dalam kehidupan masyarakat Minangkabau, bahkan generasi muda Minangkabau sudah tidak lagi mengenal surau. Namun nasip masyarakat Minangkabau tampa kehadiran surau bagaikan tubuh tampa nyawa.

\section{Treatment}

Karya dokumenter ini akan dibagi dalam tiga segmen, yang mana setiap segmen akan memaparkan tema tertentu sesuai 
dengan struktur penceritaan yang ingin dibangun.

\section{Segmen I}

Segmen I akan memberikan perkenalan tentang objek dokumenter ini yaitu bagaimana makna dan fungsi surau dalam pembentukan karakter dan budaya kehidupan masyarakat Minangkabau pada masalalu. Di awal segmen ini juga akan ditampilkan pidato Jusuf Kalla pada peresmian 11 gedung baru UNP sebagai pengantar guna memicu ketertarikan penonton terhadap dokumenter ini. Selanjutnya akan menampilkan wawancara narasumber yang akan menjadi benang merah dalam membangun struktur cerita. Poin penguatan dari statement yang disampaikan dari tiap narasumber menjadi pembangun struktur bertutur dalam menyusun narasi lewat wawancara terhadap narasumber. Latar belakang budaya dan agama yang mempengaruhi makna dan fungsi surau dalam membentuk karakter masyarakat Minangkabau akan menjadi poin penting dalam film dokumenter ini.

Isi segmen :

- Opening cuplikan pidato Muhammad Jusuf Kalla pada peresmian gedung baru Universitas Negeri Padang.

- Menjelaskan kondisi georafis Minangkabau.

- Melihatkan bangunan fisik surau yang masih terjaga.
- Melihatkan kegiatan masyarakat Minangkabau di sekitar surau.

- Melihatkan kegiatan belajar di surau

- Statement narasumber tentang sejarah, makna, dan fungsi surau.

\section{Segment II}

Pada segment ini, penonton akan diajak untuk melihat bagaimana surau mulai kehilangan makna dan fungsi dalam membentuk karakter masyarakat Minangkabau dari semua sudut pandang. Penonton akan disuguhi faktor-faktor yang menyebabkan tergesernya makna dan fungsi surau mulai dari pengaruh perang padri dan perkembangan teknologi, Semua itu akan disampaikan melalui opini dan statement dari narasumber.

Isi segmen :

- Menampilkan fisik surau yang sudah rusak.

- Statement narasumber tentang faktor-faktor kemerosotan surau.

- Gambar pendukung statement narasumber.

\section{Segmen III}

Segment ini akan menjadi penutup dari film dokumenter ini, pada segmen ini akan dibahas apakah surau masih dibutuhkan 
dalam kehidupan masyarakat Minangkabau. Bagaimana cara mengembalikian makna dan fungsi surau yang saat ini telah hilang. Semua itu akan disampaikan melalui argument argument dari narasumber yang saling diperkuat lewat stament stamement yang satu dengan yang lainnya.

Isi segmen :

- Statemnet narasumber tetang apakah surau masih dibutuhkan atau tidak dalam kehidupan mastarakat Minangkabau.

- Satement narasumber tentang bagaimana mengembalikan surau seperti awal.

\section{Tahap Perwujudan}

Karya audio visual dokumenter "Surau Kito" dibagi ke dalam tiga tahapan, yakni tahap praproduksi, produksi, dan pascaproduksi. Ketiga tahapan tersebut saling berkaitan erat, hasil dari masingmasing tahapan tersebut akan sangat berpengaruh terhadap tahapan berikutnya. Pemilihan judul "Surau Kito" dalam karya dokumenter ini dipilih karena kata "Surau Kito" berasal dari bahasa Minangkabau yang mempunyai makna bahwa surau milik kita. Pemilihan latar belakang bahasa Minangkabu dalam judul karya ini disesuaikan dengan ruang lingkup budaya kehidupan surau dalam masyarakat Minangkabau.

Konsep awal, teori, dan perwujudan karya harus memiliki kesesuaian dalam karya ini. Hal ini dapat dilihat dari konsep awal penyutradaraan, dimana karya ini menggunakan pendekatan ekspositori yang ditunjukkan lewat voice over yang disampaikan langsung oleh narasumber lewat setiap statement yang membentuk jalinan cerita secara utuh serta hubungan antar argumen yang saling memperkuat satu adegan dengan adegan lainnya untuk mengarahkan penonton pada satu tujuan dimana surau apakah masih dibutuhkan atau tidak dalam kehidupan masyarakat adat Minangkabau. Kesesuaian teori diwujudkan dengan beberapa buku panduan mengenai teori dokumenter ekspositori, seperti teori dari buku Gerzon $\mathrm{R}$ Ayawaila, Bill Nichols, dan lain sebagainya yang tercantum dalam landasan teori dalam tulisan karya ini.

\section{Praproduksi}

Praproduksi merupakan sebuah tahapan saat merancang dan merencanakan ide cerita berlangsung. Proses ini sangat penting untuk menghasilkan karya dokumenter yang baik, dimana pada tahapan ini membutuhkan kematangan agar tahapan selanjutnya berjalan lancar sesuai dengan target pembuat film. Kematangan persiapan tahapan ini menentukan hasil karya yang akan dibuat.

\section{Produksi}

Tahapan proses produksi dilaksanakan setelah treatment selesai disusun dan mendapatkan persetujuan dari 


\section{Rizqy Vajra J, Endang Mulyaningsih, Lilik Kustanto}

Bergesernya Makna dan Fungsi Surau Dalam Kehidupan Masyarakat Minangkabau Melalui Film Dokumenter

dosen pembimbing. Setiap poin per segmen menjadi dasar dalam mengolah materi serta tahap pengambilan gambar nantinya. Produksi dalam pembuatan karya film dokumenter "Surau Kito" membutuhkan waktu kurang lebih dua bulan. Secara keseluruhan proses pengambilan gambar pada film dokumenter ini dikategorikan menjadi dua bagian, yakni wawancara dan pengambilan gambar footage.

\section{Pascaproduksi}

Pascaproduksi adalah tahapan dimana pembuat film mengolah data dari proses produksi. Tahap pascaproduksi film dokumenter ini berlangsung pada bulan Januari sampai Juni 2019. Tahapan yang dilakukan merupakan proses pengarsipan data, manajemen data, preview bahan yang diperoleh pada tahapan produksi, mentranskrip hasil wawancara, pembuatan musik latar, dan editing. Proses pascaproduksi sendiri dilakukan sesuai kebutuhan dan biasanya proses pascaproduksi dokumenter dilakukan tidak hanya dalam satu waktu, mengingat pengambilan gambar dokumenter menunggu momen yang dibutuhkan.

\section{Pembahasan Karya}

Program dokumenter "Surau Kito" mengetengahkan cerita tentang bagaimana makna dan fungsi surau dalam membentuk karakter masyarakat Minangkabau beserta konfliknya saat surau kehilangan makna dan fungsinya dalam kehidupan masyarakat
Minangkabau, di mana para narasumber dalam dokumenter ini menjadi penyampai pesan subjektif sebagai penyambung benang merah cerita. Terdapat dua narasumber utama dalam karya ini yang masing- masing mempunyai kompetensinya berdasarkan kebutuhan naratif serta kedudukannya dalam lingkungan kehidupan surau, dan kesemuanya merupakan penggiat dan pemerhati surau yang mempunyai latar belakang yang berbeda. Konflik terhadap merosotnya kehidupan surau dalam membentuk karakter masyarakat Minangkabau dimunculkan lewat penuturan narsumber yang disertai oleh gambar gambar surau yang mulai roboh dan ditinggalkan.

\section{Segmen I}

Pada segmen satu menampilkan perkenalan objek dan subjek dalam film dokumenter "Surau Kito" ini sekaligus memberikan sedikit pengenalan konflik terhadap surau dalam kehidupan masyarakat adat Minangkabau, pengenalan karakter karakter utama atau narasumber utama dalam segmen ini dilakukan melalui visual dan wawancara. Pada opening film "Surau Kito" ini akan menampilkan potongan

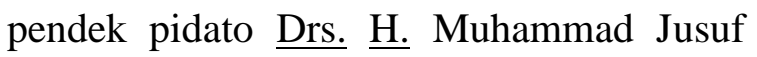
Kalla pada saat peresmian gedung baru Universitas Negri Padang, opening ini guna untuk membuka tema serta konflik mengenai isu surau dalam kehidupan masyarakat Minangkabau, statement dari

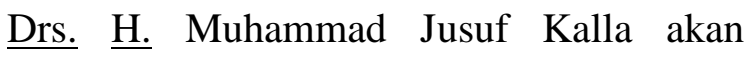


membuat penonton lebih tertarik dan tertantang untuk melihat konten berikutnya.

Fokus utama materi dalam segmen ini adalah mengenai sejarah, makna, sesuai dengan poin yang ingin disampaikan dalam segmen ini. Ritme adegan yang terkesan lambat menjadi kendala dalam menyusun gambar dalam setiap adeganya.

\section{Segmen II}

Pada segmen ini, konflik terhadap faktor kemerosotan surau dalam pembentukan karakter masyarakat Minangkabau mulai dimunculkan, konflik tersebut menjadi bagian utama dalam segmen ini. Bagaimana surau kehilangan peranan dalam kehidupan masyarakat Minangkabau menjadi topik yang dibahas pada segment ini. Pada segment ini akan dimulai dari statement dari salah satu tokoh masyarakat yang menjelaskan bagaimana Undang-Undang desa yang ditetapkan oleh pemerintahan pada masa orde baru meneybabkan perpecahan dalam sistem kepemimpinan desa adat di Minangkabau yang berimbas kepada surau.

Segment ini ditujukan untuk membangun konstruksi pemikiran penonton bahwa memang banyak faktor dan unsur dalam masyarakat Minangkabau yang mempengaruhi perkembangan surau dalam membentuk karakter masyarakat Minangkabau.

\section{Segmen III}

Pada segmen ini, isi film lebih mengarah kepada pendapat akhir masingmasing narasumber tentang penting atau tidaknya lagi kehadiran surau dalam kehidupan masyarakat Minangkabu, sekaligus sebagai kesimpulan dari pembahasan mengenai tema surau secara global. Kesimpulan lebih menekankan bahwa semua kembali kepada masyarakat Mianangkabau itu sendiri yang akan memutuskan bagaimana mereka menghidupkan surau lagi.

\section{Penutup}

Setiap proses pembuatan film dokumenter akan memiliki ciri khas dan cerita masing-masing sesuai dengan tema dan narasumber atau objek yang dipilih. Meskipun film dokumenter berbeda dengan film fiksi, pada dasarnya secara keseluruhan proses pengerjaannya tetap dengan cara atau metode yang sama, yaitu secara sistematis, dan terencana. Perbedaanya hanya pada proses produksi sebuah film dokumenter dibutuhkan kepekaan untuk lebih sering mendengar pendapat dan ilmu tambahan dari luar, dan lebih cepat dalam mengambil keputusan yang paling baik bagi proses produksi, dan hasil film dokumenternya.

Dokumenter biasanya identik dengan jumlah crew yang sedikit, hal tersebut karena akan lebih efektif ketika proses pengambilan gambar film dilakukan, dan akan lebih membuat narasumber lebih nyaman, sekaligus untuk meminimalisir intervensi crew pada narasumber atau 


\section{Rizqy Vajra J, Endang Mulyaningsih, Lilik Kustanto}

Bergesernya Makna dan Fungsi Surau Dalam Kehidupan Masyarakat Minangkabau Melalui Film Dokumenter

objek yang akan diambil gambarnya, sehingga momen yang dikejar akan tetap didapatkan gambarnya.

Rintangan selanjutnya dalam penggarapan sebuah film dokumenter dengan gaya ekspositori adalah bagaimana membuat film tersebut tidak membosankan meskipun kontennya terdiri dari banyak statement saja. Yaitu dengan memanfaatkan tiga unsur dalam film, seperti unsur visual, suara, dan editing. Musik sangat membantu dalam pembentukan tempo dan transisi pada setiap pergantian babak atau segment pada film dokumenter ini, selain itu musik juga dimanfaatkan untuk membuat mood penonton agar tidak bosan.

Garis besar kesimpulan proses pembuatan film dokumenter "Surau Kito" ini berjalan dengan lancar, dan tanpa kendala yang berarti, serta dapat sesuai dengan konsep yang direncanakan diawal. Faktor-faktor budaya, sosial dan alam selalu memengaruhi proses riset dan produksi pada film dokumenter ini, dan hal itu sudah menjadi hal yang biasa ketika membuat sebuah film dokumenter. Diharapkan film dokumenter ini dapat menjadi bahan diskusi dan acuan dalam pengembalian kehidupan surau agar dapat membentuk karakter masyarakat Minangkabau kembali.

\section{Daftar Pustaka}

Abidin, M. (2016). Tiga Sepilin: Surau Solusi Untuk Bangsa. Yogyakarta: CV. Gre Publishing

Ayawaila, G. (2008). Dokumenter: Dari Ide Sampai Produksi. Jakarta: FFTV-IKJ Press.

Bernard, C., \& Sheila. (2007). Documentary Storytelling (2nd Edition ed.). United Kingdom: Focal Press.

Fachudhin, A. (2012). Dasar-Dasar Produksi Televisi. Jakarta: Kencana Prenada Media Grup.

Gantang, I. G. (2017, August 30). (N. L. Anjani, Interviewer)

Hanani, S. (2002). Surau Aset Lokal Yang Tercecer. Bandung: Humaniora Utama Press

Imanudin, I. (2002) Dinamika Kehidupan Surau Di Minangkabau (Kasus Di Nagari Paringan, Kab. Tanah Datar 1969-1990.). Padang: Badan Pengembangan Kebudayaan Dan Pariwista Balai Kajian Sejarah Dan Nilai Tradisional

Mangkuto, M (2018, Maret 12). (Rizqy Vajra, Interviewer) Mangkuto, J (2018, Maret 22). (Rizqy Vajra, Interviewer)

Mascelli, J. V. (2010). Five $C^{\prime} s$ of Cinematography (Second Edition ed.). (H. M. Biran, Penerj.) Jakarta: FFTV IKJ.

Pratista, H. (2017). Memahami Film (Edisi 2 ed.). Yogyakarta: Montase Press.

Tanzil, C. (2010). Pemula Dalam Film Dokumenter: Gampang-Gampang Susah. Jakarta: In-Docs.

Wibowo, F. (1997). Dasar-Dasar Program Televisi. Jakarta: PT. Grasindo. 